\title{
Vida e Trabalho no Mundo Rural: Trabalhadores do Movimento de Educação de Base (1961-1964)
}

Claudia Moraes Souza

Resumo: $\mathrm{O}$ artigo em questão, "Vida e Trabalho no Mundo Rural: Trabalhadores do Movimento de Educação de Base", trata do camponês do MEB. Fomos à busca das informações acerca da situação fundiária e das condições de trabalho do camponês, situando-os na organização social e econômica do estado de Pernambuco, nos idos dos anos 60. Resgatamos a diversidade das situações de trabalho do aluno do MEB, apontando o sentido político que a identidade camponesa adquiriu no momento da modernização da economia canavieira nordestina. No MEB, o camponês demarcou a sua identidade de trabalhador da terra levantando demandas que legitimavam seus direitos à terra e seus direitos no trabalho.

Palavras-chaves: Educação rural - trabalhador rural - Cultura Camponesa

Abstract: The article in question Life and Work in Rural World: Workers' Education Movement of Base is the peasant of MEB. We went in search of information about the land situation and working conditions of peasant placing them in the social and economic organization of the Brazilian northeast back in the 60s. Rescued the diversity of the work situation of the student MEB pointing the political sense that the identity peasant acquired at the time of the modernization of the sugar economy in the Northeast. In MEB, the peasant has set out its identity as a worker of the earth rising demands that legitimized their rights to land and their rights at work.

Keywords: Rural education - farm worker - Rural Culture.

"É como seres conscientes que mulheres e homens estão não apenas no mundo, mas com o mundo. Somente homens e mulheres como seres abertos são capazes de realizar a complexa operação de simultaneamente, transformando o mundo, através da sua ação, captar a realidade $e$ expressá-la por meio da linguagem criadora."

(Paulo Freire)

\section{SOBRE AS ORIGENS DO MEB}

No período que envolve os dois últimos anos da década de 50 e o tumultuoso ano de 1964, o Movimento de Educação de Base (MEB) figurou na cena nacional juntamente com outros importantes movimentos voltados à educação e à cultura popular, dentre eles os

\footnotetext{
* Professora do Centro Universitário Faculdades Integradas de Osasco, UNIFIEO. Doutora em História Social pela USP.
} 
Centros Populares de Cultura (CPCS) da União Nacional dos Estudantes (UNE), o Movimento de Cultura Popular (MCP) de Pernambuco, nas dimensões municipal e depois estadual do governo Miguel Arraes, e a Campanha De Pé no Chão Também se Aprende a Ler, do governo do Rio Grande do Norte. Na diversidade dos movimentos, o MEB conquistou posição de destaque, dado o seu caráter de movimento oficial garantido na articulação política entre o Governo Federal e a CNBB, em sua dimensão territorial e na inovação tecnológica advinda das proposições da radiodifusão educativa.

Trata-se - o MEB - de um movimento de educação e cultura popular fundado nos preceitos da educação de base, instituído oficialmente em 1961 a partir de ações e mediante acordo entre a Confederação Nacional dos Bispos (CNBB) e o Governo Federal. A iniciativa permitiu a criação e o funcionamento de uma rede escolar radiofônica em diferentes áreas do território brasileiro.

Em 1960, o MEB constituiu uma rede de 5 sistemas educativos em Pernambuco e na Paraíba, com origem em iniciativas isoladas da diocese comandada por Dom Eugenio Sales. Ao se tornar um movimento nacional, em 1964, a rede fora ampliada para o número de 60 sistemas. O auge de sua ação no território nacional se deu em 1963, instalando-se em 15 unidades federativas, a saber: as regiões Nordeste, o Centro-Oeste, o estado de Minas Gerais e a região amazônica. Calcula-se o envolvimento de cerca de 400.000 alunos, de 63 diferentes cidades, na rede radiofônica do MEB, entre os anos de 1960 e 1964.

A rede de escolas formada atingiu o território interligando, via rádio, as áreas rurais do interior dos estados aos centros urbanos onde funcionavam as centrais educativas radiofônicas. No mapa a seguir podemos observar a instalação dos sistemas radiofônicos pelo território nacional (Figura 1): 


\section{MAPA DOS SISTEMAS RADIOFÔNICOS}

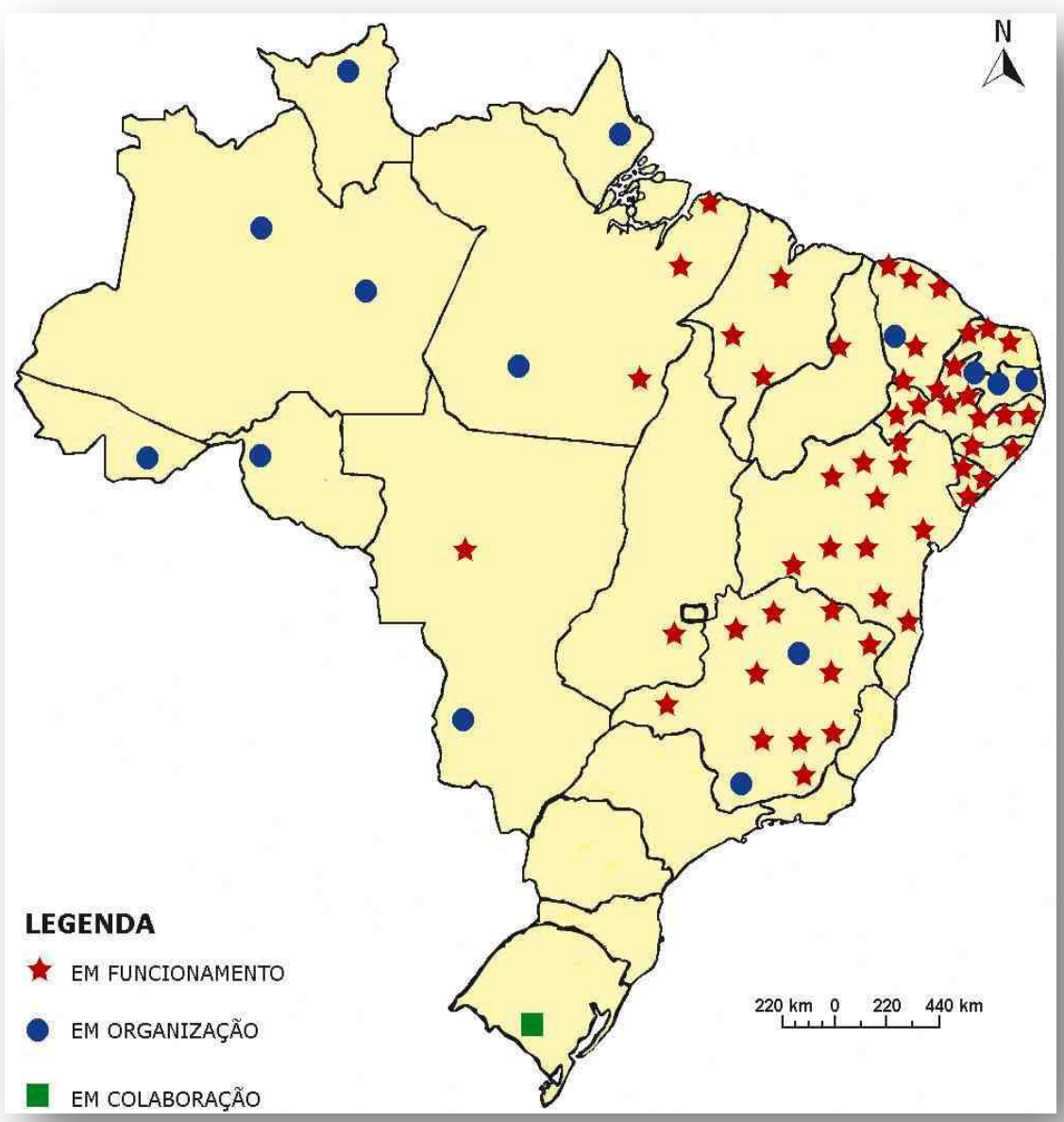

Figura 1. Mapa dos Sistemas de Rádio entre 1961-1963. Elaborado a partir da Fonte: MEB/NACIONAL, Relatório Anual, 1963.

Além das amplas dimensões espaciais e numéricas, o MEB foi o mais longo movimento de educação popular a atuar dentre todos os seus pares. Oficializado por decreto em 1961, resistiu ao golpe militar de 1964, mantendo seu funcionamento até 1968 e conseguindo resistir, com formato diferenciado, até hoje.

Nos anos 60 sua ação tinha por base a escola radiofônica, o verdadeiro núcleo onde acontecia a comunicação entre professores do MEB (professores-locutores), monitores e alunos das comunidades rurais. Os esforços das equipes estaduais, em cada lugar em que o programa foi implantado, voltaram-se para o funcionamento de um conjunto de Centros Radiofônicos, nos quais se alojavam as equipes locais que, conectadas às Escolas Ecumênicas Rurais Radiofônicas (EERRs), formavam um Sistema Radioeducativo. 
No Movimento de Educação de Base (MEB) figuraram o episcopado brasileiro, a hierarquia de padres e freiras católicas, o laicato, estudantes, militantes partidários, educadores, técnicos educacionais e uma grande massa numérica de camponeses analfabetos ou de pouca escolarização, todos compactuando de ideias que tratavam a cultura como ferramenta política capaz de transformar as representações do mundo e $a$ própria dura realidade material (BRANDÃO, p. 32, 2002). Essa diversidade de sujeitos, na composição do MEB, permitiu que este se destacasse na constelação nacional de movimentos político-culturais da efervescente e romântica década de 60 (RIDENTI, 2000), não apenas como um movimento de educação popular de caráter massivo, devido à sua proposição de radiodifusão educativa, mas também no que se relacionava à sua diversidade político-cultural.

O objetivo deste artigo é abordar o sistema radioeducativo de Nazaré da Mata, região de Pernambuco em que a atuação do MEB foi decisiva na organização dos trabalhadores rurais em seu processo de sindicalização rural, transpondo objetivos meramente alfabetizadores das ações educacionais.

\section{e a Escola Chegou}

Em 16 de maio de 1961, da diocese de Nazaré da Mata, Padre Petrolino Pedrosa, diretor do Centro Radiofônico de Educação Rural, informava por carta à supervisora Marliete Pessoa, membro de sua equipe, a formação de 15 Escolas Radiofônicas que agregavam um total de aproximadamente 400 alunos, na região da Mata Norte de Pernambuco.

Formado em meados de abril, o Centro Radiofônico de Educação Rural de Nazaré da Mata funcionou ativamente no ano de 1961, tendo concluído o ano letivo no mês de dezembro com um total de 41 escolas e cerca de 1.100 alunos $^{1}$.

Neste centro, padre Petrolino e sua equipe de professoras-locutoras - Neide Veiga e Terezinha B. Correia - planejavam, produziam e emitiam a programação educativa das Escolas Ecumênicas Radiofônicas Rurais (EERRs), possibilitando o funcionamento de um

\footnotetext{
${ }^{1}$ MEB/PERNAMBUCO. Relatório Anual da Equipe Estadual de Pernambuco. 1961. Fundo MEB-CEDIC.
} 
sistema de educação rural a distância, pertencente ao MEB, que cobria ampla região da Mata Norte de Pernambuco.

Um rádio receptor, o conjunto didático composto de cartilha e livros de leitura, uma lousa, cadernos e lápis eram os elementos necessários para a formação de uma escola radiofônica. Além desses recursos, a escola de rádio dependia da dedicação e boa vontade do monitor, trabalhador voluntário com mínima escolaridade que era escolhido entre os membros da própria comunidade em que a escola se instalava.

O Movimento de Educação de Base (MEB) e a Representação Nacional de Emissoras Católicas (RENEC), ambos com sede no Distrito Federal, assim definiram a Escola Radiofônica Rural:

(...) Um professor num microfone, multiplicando por 10, 100 e 1.000 outros professores, graças a uma rede radiofônica de recepção organizada, de imensa simplicidade, onde em cada unidade está um receptor e junto dele um modesto monitor, obedecendo às vozes de um comando que vem de longe, mas vêm redentoras, ensinando a ler, a escrever, a contar, ensinando elementos da agricultura, de educação sanitária, de higiene, de moral, de economia geral, de economia doméstica, de vida cívica e espiritual, dando a milhares de homens e mulheres, moços e adolescentes, a notícia do que vai pelo mundo, pelo seu país, pelo seu estado, pelo seu território e pelo seu meio $(. . .)^{2}$.

A potencialidade da tecnologia do rádio estava sendo utilizada, segundo a Igreja Católica, para multiplicar a capacidade de alcance da educação de adultos. Desta maneira, o MEB, gerado no seio das ações da Confederação Nacional dos Bispos do Brasil, demonstrava preocupações com a urgência de ações interventoras sobre problemas sociais, econômicos e políticos em determinadas regiões brasileiras e principalmente no Nordeste ${ }^{3}$. Neste cenário, o MEB apresentou-se, na diversidade de mediadores e agentes educacionais, como um movimento organizado disposto a ações efetivas sobre as populações imersas na carência econômica. Como programa educacional lê-se no Plano Quinquenal sua propositura:

(...) O Movimento de Educação de Base é uma solução concreta para situações bem definidas de zonas subdesenvolvidas, onde está sendo impossível chegar a escola

\footnotetext{
${ }^{2}$ MEB/NACIONAL. Plano Qüinqüenal. $S / d$. Fundo MEB-CEDIC.

${ }^{3} \mathrm{~A}$ intervenção da Igreja se fez nesse momento por uma vertente conservadora. José de Souza Martins identificou a interpretação católica da situação do meio rural como propositora de uma ação entre camponeses, que disputava espaço político com o Partido Comunista Brasileiro e outras instituições à esquerda. Posteriormente, especificamente após 1968, Zilda Márcia Grícoli lokoi identificou um setor progressista da Igreja Católica proponente de reformas sociais, de uma reforma agrária mais radical e de ações de combate à miséria, em países como o Peru e o Brasil. IN: MARTINS, José de Souza, Os Camponeses e a Política no Brasil, Petrópolis: Vozes, 1981. p. 81; e IOKOI, Zilda Márcia Gricoli. Igreja e Camponeses, São Paulo: Hucitec, 1996. p. 31-32.
} 
tradicional. O processo educacional é por conseqüência condicionado à situação do povo, tanto do camponês quanto do trabalhador urbano das zonas extremamente necessitadas. Alinguagem dos programas de cada emissora atende à situação e aos problemas locais, visto que as equipes encarregadas de elaborá-los são especialmente treinadas para este fim $(\ldots)^{4}$.

Nesta perspectiva, a Escola Radiofônica deveria chegar massiva e eficazmente à família rural. Sua dinâmica foi concebida visando à funcionalidade escolar, à desburocratização e à democratização do acesso à escola, pois somente assim, no pensamento do MEB, poderia ser consolidado o projeto de educação e cultura popular nas comunidades almejadas.

\section{O CAMPONÊS DO MEB}

De cada pequena localidade rural do Nordeste, o MEB recebia matrículas em que os alunos, inscritos na escola de rádio, declaravam suas ocupações e/ou profissões. Nessas listas constavam recorrentemente as mesmas declarações; ao lado do nome e da idade dos alunos, surgiam as inscrições: sitiante, agricultor ou lavrador:

Bela Rosa, 22 de junho de 1962.

Boas supervisoras

Vai nesta carta os nomes de meus novos alunos:

Marina Salvina da Conceição, nascida a 27/8/1925, de profissão doméstica, solteira.

Benedito Inácio da Silva, nascido a 8/9/1945, profissão de agricultor e solteiro.

José Inácio da Silva, nascido a 7/1/1947.

José Liberato da Silva, nascido a 20/8/1947, agricultor, solteiro.

José Sebastião da Silva, nascido a 22/2/1945, profissão agricultor, solteiro. José Guedes Alcoforado, nascido a 13/4/1950, profissão agricultor, solteiro.

Estes foram os que entraram no mês de maio na escola.

Desejo a todas um feliz São João.

Atenciosamente

Ana Felisberto ${ }^{5}$.

Foi prática dos monitores/as do MEB apresentarem a lista de nomes masculinos e femininos sempre acompanhados da ocupação e/ou profissão do aluno. Nesta, e em outras

\footnotetext{
${ }^{4} \mathrm{MEB} / \mathrm{NACIONAL}$. Plano Qüinqüenal, s/d. Fundo MEB-CEDIC.

${ }^{5} \mathrm{~A}$ partir deste momento do texto diversas cartas dos alunos e monitores do MEB serão aqui reproduzidas, sendo identificadas apenas pela assinatura do emissor e data. As cartas compõem o fundo MEB, pertencente ao CEDIC-PUC/SP. Optamos pela reprodução das cartas com as devidas correções gramaticais e ortográficas.
} 
cartas trocadas entre os Centros Radiofônicos do MEB e as escolas, percebemos que aos alunos do sexo masculino associavam-se as profissões de agricultor, lavrador ou sitiante, e que nas declarações acerca das alunas prevalecia a citação do trabalho doméstico como ocupação principal.

As cartas revelam uma fala do trabalhador sobre si, ele fora questionado quanto a sua profissão, e como resposta se apresentava como agricultor, sitiante ou lavrador. Neste conjunto de falas, o trabalhador se autorrepresentava baseado em uma atividade vivenciada em relações de produção familiar. Nesta representação, o trabalho do qual se ocupava o articulava ao principal meio de produção - a terra -, criando um sentido que o definia como um grupo social. Com esta atitude, o grupo de trabalhadores do MEB definiu-se a partir de sua interligação com a terra, situando-se política, cultural e economicamente em relação à terra e aos meios de produção numa situação direta de uso e/ou posse.

Assim, o grupo social estudado demonstrou haver elaborado uma consciência própria de sua situação de classe. O contato direto com a terra o fez identificar-se como agricultor ou lavrador, independentemente da relação de propriedade, ou não, da terra como meio de produção. A identidade construída a partir da relação com a terra (e não com a propriedade) nos levou à opção pela adoção do conceito de camponês para tratarmos o referido grupo, tendo o cuidado de referenciarmo-nos ao intenso debate conceitual travado por gerações de intelectuais acerca do conceito de camponês e à polêmica sobre a existência ou não do campesinato no Brasil.

O entendimento do camponês como categoria que participa da formação social e econômica brasileira exige, primeiramente, um esforço de interpretação que rompa com modelos rígidos de periodização histórica e organização social e econômica. Este esforço interpretativo vem sendo realizado, ininterruptamente, por um pensamento crítico, dentro e fora do Brasil, que, superando e ampliando noções estruturalistas, propõe a ruptura com o entendimento homogêneo da classe camponesa, levantando uma discussão acerca da heterogeneidade deste(s) grupo(s) social(s) e suas especificidades ${ }^{6}$.

\footnotetext{
${ }^{6}$ Desde meados da década de 60, Teodor Shanin tem se destacado como teórico inovador na discussão conceitual acerca das sociedades camponesas. Retomando A. V. Chayanov e a ideia de uma organização diferenciada ou específica do camponês no processo de desenvolvimento do sistema capitalista, Shanin propôs a ruptura com o entendimento homogêneo da "classe camponesa", promovendo uma discussão sobre a heterogeneidade deste grupo e suas especificidades. Segundo Shanin, predominantemente até a década de 60,
} 
O grupo social que analisamos situa-se num universo de trabalhadores da terra que exclui toda e qualquer possibilidade de um conceito clássico de camponês ${ }^{7}$. A problemática da heterogeneidade e especificidade do grupo social referido supõe o rompimento com os conceitos convencionais, levantando, inclusive, a ilegitimidade de um conceito mistificado acerca de um grupo social que, por princípio, possui conteúdos históricos diferenciados em sua formação e organização socioeconômica e política.

Segundo Shanin ${ }^{8}$ podemos categorizar o camponês porquanto desvendamos seu modo de vida articulado aos diferentes espaços e tempos históricos em que se manifesta. Em outras palavras, diferentemente do conceito de um modo de produção camponês, devemos operar com a noção de campesinidade entendida como um modo genérico de organização econômica, social, política e cultural, recuperando do vivido alguns elementos universais, tais como a unidade familiar, a produção para autoconsumo, as relações com o tempo cíclico da natureza, os ritos e festas ancestrais, a religiosidade etc.

A campesinidade é o que distingue o camponês em relação a outros grupos sociais. Para Shanin, essas distinções podem estabelecer-se genericamente: em uma economia camponesa que se pauta por formas próprias, por padrões e tendências da organização política, por normas e cognições típicas do campesinato, por uma organização social característica pautada na família, na comunidade, na aldeia.

\footnotetext{
as abordagens marxistas mais ortodoxas, seguidoras do pensamento de Lênin, trataram o camponês sob duas óticas: primeiro, a perspectiva da "diferenciação", em que no interior da sociedade camponesa os processos de diferenciação social se acirram e consequentemente levam o camponês a assumir novo modo de vida, ou seja, passa a ser "outro" e não mais camponês; segundo, a perspectiva dos "modos de produção" que discutia a procedência de ser ou não o modo de vida do camponês um modo de produção dotado de estrutura política e econômica autossuficientes. Ambas as perspectivas, por sua vez, definem o camponês como um grupo de características homogêneas e que tende ao desaparecimento no processo de desenvolvimento do capitalismo. O debate suscitado por Teodor Shanin compõe um quadro de debates acerca do campesinato em que se polarizam visões e tendências: de um lado, proposições modernizantes do paradigma do capitalismo agrário, e, de outro, visões e tendências antropológicas e sociológicas voltadas ao entendimento do camponês enquanto grupo social diferenciado, porém componente do sistema capitalista. Ver: SHANIN. T. Naturaleza y Logica de la Economia Campesina, p. 07 -79. Barcelona: Anagrama, 1979.

${ }^{7}$ Quando dizemos não ser o camponês brasileiro o campesinato no sentido clássico, pensamos nas diferenças históricas que envolvem o camponês brasileiro e o campesinato definido por Marx e Lênin. O camponês brasileiro, segundo Martins, é uma classe gestada com a expansão capitalista, sendo produto do rol de contradições desta expansão. Assim, o camponês brasileiro não foi proprietário de terras desde o início; sua luta constante foi a da conquista da terra, diferentemente do camponês clássico, caracterizado por Lênin como proprietário de terras e resistente à expansão capitalista. Ver: MARTINS, J. S. Os Camponeses e a Política no Brasil, p. 26-31.

${ }^{8}$ SHANIN,T. A Definição do Camponês: Conceituações e Desconceituações. Cadernos estudos CEBRAP, n. 26, São Paulo: CEBRAP, 1980.
} 
Henri Lefebvre ${ }^{9}$ fala de um mundo camponês não no sentido de uma realidade isolada, mas em razão de sua extraordinária variedade e de características próprias. Articulando este pensamento à noção de campesinidade, poderíamos entender as manifestações procedentes das sociedades camponesas em função de suas características particulares, e, ao mesmo tempo, genéricas, como também em suas conexões com a modernidade do capital que o subsumiu à sua lógica.

Tratando do Brasil, José de Souza Martins ${ }^{10}$, ao observar a emergência das lutas sociais no campo, estabeleceu uma noção de camponês a partir da luta política assumida por grupos sociais ligados à terra. Ou melhor, para Martins, camponês é uma palavra política que estes grupos procuraram dar a si mesmos tentando expressar uma unidade de classe. Esta noção exige de nós a atenção ao fato de que os conflitos no campo devem ser explicados pela ação política da classe, diante dos ritmos e tempos históricos diferentes que o processo de desenvolvimento capitalista assumiu no território brasileiro.

Por essas noções apreendemos que o camponês assume posição de classe quando se reconhece na diversidade, na generalidade e na história. Posto isso, podemos dizer que estes grupos sociais, como classe, estiveram presentes na sociedade brasileira desde os primórdios da sociedade escravista, uma vez que, no engenho, relações diversas com a terra estabeleceram padrões de uso e de posse variados, permitindo a convivência secular de lavradores, posseiros, moradores e rendeiros com a plantation ${ }^{11}$. Na medida em que, historicamente, se perpetuou o monopólio sobre a terra, alimentaram-se em nossa formação econômica as possibilidades múltiplas de arranjos políticos e econômicos entre proprietários e subordinados, o que intensificou a diversificação das relações sociais no campo.

Daí podermos falar em um camponês do MEB caso seja considerada a heterogeneidade dos grupos sociais que participaram das escolas, a existência de um modo de vida que caracterizava estes grupos, além de um conjunto de relações de uso, posse e trabalho na terra que podem ser assimiladas em uma definição não homogênea de camponês.

\footnotetext{
${ }^{9}$ LEFEBVRE, H. De lo Rural a lo Urbano. Barcelona: Ediciones Peninsula, 1978.

${ }^{10}$ MARTINS, J. S. Os camponeses e a Política no Brasil. Petrópolis: Vozes, 1986.

${ }^{11}$ FORMAN , Shepard. Camponeses: sua Participação no Brasil, p. 47-53. Rio de Janeiro: Paz e Terra, 1979.
} 
O que sabemos do camponês do MEB resulta de dois tipos de fontes: aquelas produzidas pelo MEB como documentos oficiais de planejamento, orientação e avaliação do projeto educacional, e todo um conjunto documental (cartas, bilhetes, cordel, versos) produzido nas escolas radiofônicas rurais por monitores e alunos, em face da necessidade de comunicação e interação da escola com as equipes de rádio.

Os documentos produzidos pelas equipes nacional e estadual trataram os sujeitos sociais, para os quais o projeto se constituiu, como camponeses. O MEB estabeleceu, em suas declarações iniciais, a preocupação com uma população eminentemente rural, local, atribuindo genericamente a esta população o conceito de camponês, homem do campo ou homem rural. Demonstrou-se incisivamente, no discurso do projeto de alfabetização e de cultura popular, a definição de um público-alvo: o camponês adulto ${ }^{12}$.

Ao propor um trabalho educacional construído a partir da realidade local, o MEB preocupou-se em orientar as equipes para conhecer e caracterizar a realidade local através de estudos da realidade ou estudos de área, atentando para a diferenciação das condições econômicas e sociais que o homem rural poderia apresentar em diferentes espaços regionais. Não tivemos acesso a um estudo de área sequer, no entanto, analisando roteiros destes estudos, percebemos uma iniciativa voltada para a interpretação da realidade local, que almejava conhecer os problemas, necessidades e recursos disponíveis nas comunidades atingidas. Especificamente em relação ao aluno-trabalhador, buscavam-se caracterizar as técnicas do trabalho agrícola regional, as relações de trabalho e a organização da comunidade para a produção. Desta documentação obtivemos também informações que nos permitiram estimar o número de alunos envolvidos, assim como as características etárias do camponês que se matriculou no MEB.

As escolas rurais do MEB receberam entre 1961 e 1965 um número equivalente a 400.000 (quatrocentos mil) alunos, caracterizados pelo MEB/Nacional como uma população de adolescentes e adultos das áreas rurais subdesenvolvidas do país ${ }^{13}$. Utilizando-se de um sistema de amostragem entre 1963-1964, o MEB calculou a percentagem da distribuição numérica de seus alunos por faixa etária, verificando que o maior percentual de alunos se concentrava na faixa etária de 15 a 30 anos, constatando a existência de uma faixa

\footnotetext{
${ }^{12}$ MEB/NACIONAL. MEB em 5 anos. 2ạ edição, 1982. Fundo MEB-CEDIC.

${ }^{13}$ Ibid., p. 75.
} 
percentual significativa de alunos com idade inferior a 15 anos $^{14}$, e a existência de um terceiro percentual de alunos acima de 50 anos (Figura 2).

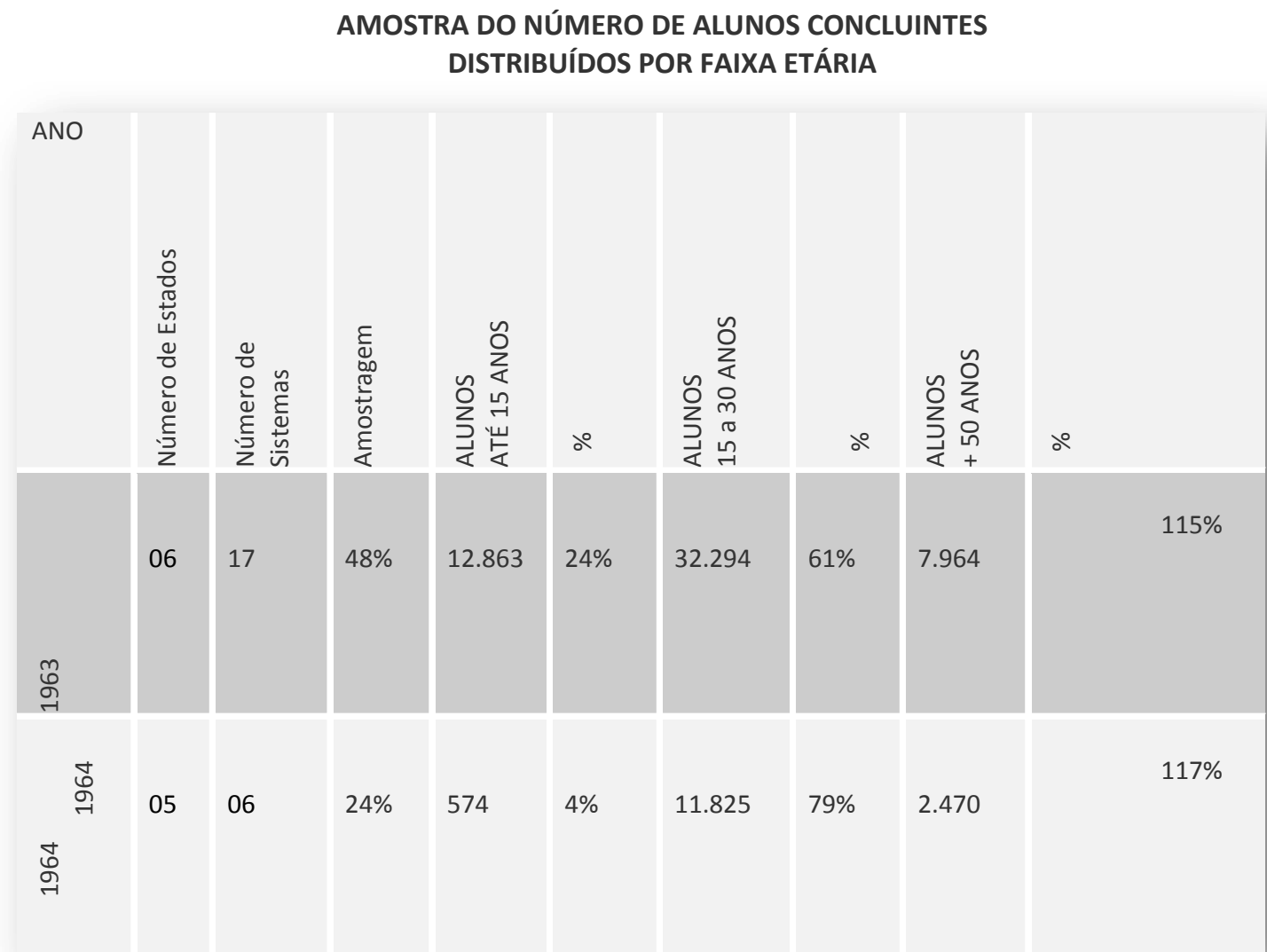

Figura 2. Tabela de alunos concluintes por faixa etária. Fonte: MEB-NACIONAL. MEB em 5 anos. 1982.

Mesmo com preocupações voltadas para o entendimento das realidades locais - os documentos nacionais, a programação do rádio, os documentos e relatórios dos encontros de coordenação -, a comunidade rural foi enfocada sob uma perspectiva homogênea. Este problema foi percebido na dinâmica do próprio MEB em momentos de avaliação de trabalhos.

Ao final de quase dois anos, em 1962, coordenadores do movimento perceberam que algumas equipes não faziam levantamentos locais, outras não interpretavam e/ou não se

\footnotetext{
${ }^{14}$ Insistentemente a direção do MEB posicionava-se contra a participação de crianças de idade inferior a 15 anos nas escolas de rádio, no entanto, a inexistência de escolas em algumas comunidades, ou mesmo o trabalho infantil, levaram monitores a aceitar crianças de 11, 12, 13 e 14 anos nas aulas noturnas. Encontramos no fundo MEB diversas cartas que tratam desta situação.
} 
utilizavam de dados coletados para o trabalho educacional e o preparo dos cursos radiofônicos, desprezando-se diferenças e estabelecendo-se simplificações da riqueza cultural e diversidade regional das comunidades rurais ${ }^{15}$. A fim de nos aprofundarmos na caracterização do referido grupo de camponeses, partimos em busca do resgate das condições de existência do camponês local, na tentativa de examinar a realidade vivida por estes camponeses na heterogeneidade característica da classe.

\section{O CAMPONÊS EM NAZARÉ DA MATA}

Optamos assim pelo aprofundamento do tema em um estudo verticalizado do cotidiano de um único Centro Radiofônico, que teve sede em Nazaré da Mata e agrupou as áreas rurais de vários municípios da Mata Norte de Pernambuco. Nesta região funcionou ativamente o Centro de Escolas Rurais Radiofônicas de Nazaré da Mata (CERR).

A área de atuação do sistema de Nazaré localizava-se a noroeste da Zona da Mata, estabelecendo-se em uma região denominada de transição entre Mata e Agreste, caracterizando-se fisiograficamente como uma região de três domínios: a Mata, com domínio da cana-de-açúcar; o Agreste, que mesclava atividades pecuárias e agrícolas de subsistência e comerciais; e, por fim, o Brejo, que comportava inclusive a policultura ${ }^{16}$ (Figura 3).

\footnotetext{
${ }^{15} \mathrm{MEB} / \mathrm{NACIONAL}$. I Encontro de Coordenadores/Conclusões I. 1962. Fundo MEB-CEDIC.

${ }^{16}$ ANDRADE, M. Correia de. A Terra e o Homem no Nordeste: contribuição ao estudo da questão agrária no NE, p. 31. São Paulo: Brasiliense, 1998.
} 
MAPA DE PERNAMBUCO SUBDIVIDIDO EM MESORREGIÕES

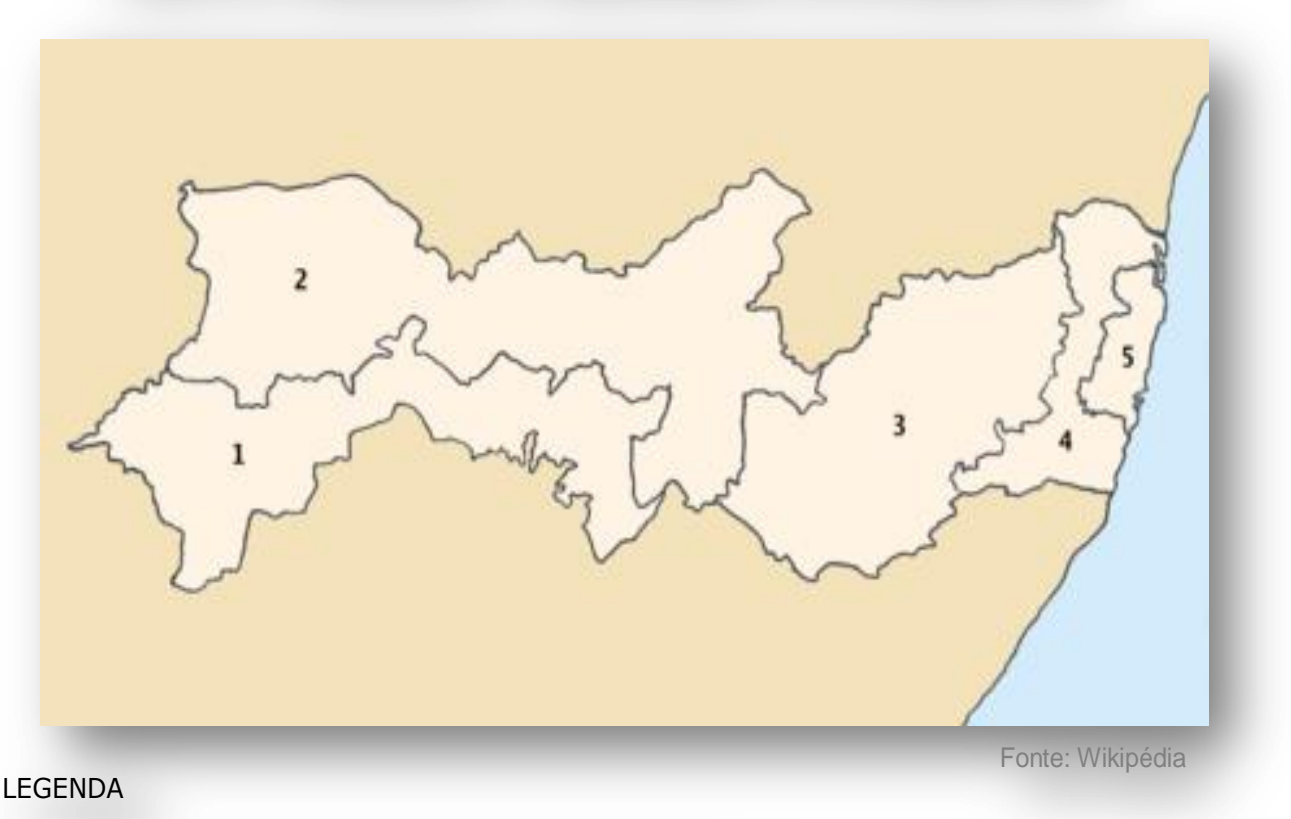

1. Mesorregião do São Francisco Pernambucano

2. Mesorregião do Sertão Pernambucano

3. Mesorregião do Agreste Pernambucano

4. Mesorregião da Mata Pernambucana

5. Mesorregião Metropolitana do Recife

Figura 3. Mapa das Mesorregiões de Pernambuco. Fonte: Wikipédia.

Por meio do engenho, na Mata Norte, criou-se, desde tempos coloniais, uma sociedade camponesa de lavradores - foreiros moradores ou condicioneiros - que concentrou populações em torno da casa-grande e, posteriormente, formou um hábitat disperso no engenho, distribuindo, através de amplos espaços, as habitações de trabalhadores, que recorriam, por vezes, às localidades, vilas e cidades para suprir suas necessidades básicas ${ }^{17}$.

Estudos aprofundados sobre o Nordeste e sua formação social e econômica demonstraram a intensa diversificação de relações de posse e uso da terra, própria das relações de produção das regiões monocultoras, para além do regime de escravidão. Desde o século XIX o trabalhador livre começou a substituir o escravo, devido ao alto custo do

\footnotetext{
${ }^{17}$ GRABOIS, J. Que Urbano é Este? O habitat num espaço de transição do norte de Pernambuco. IN: Estudos Avançados/USP. Dossiê Nordeste Seco. Instituto de Estudos Avançados. São Paulo: IEA, vol.1, no. 01. 1987. P. 79-99.
} 
escravo negro e a venda desta mercadoria para o Sudeste cafeeiro. Este fato fazia com que a relação de morada ou morada de condição viesse a se tornar uma relação predominante na cana $^{18}$. A origem da condição baseava-se na existência de homens livres, destituídos da propriedade, que se colocavam sob a tutela de um senhor de engenho, com permissão para morar, levantar choupana de barro e dar 2 ou 3 dias de trabalho para o senhor ${ }^{19}$, como alternativa de sobrevivência econômica na terra e proteção familiar.

O morador residia nas terras do engenho, detendo o direito do uso para o plantio de lavoura branca - milho, mandioca, feijão - como parte constitutiva da relação de morada, ao mesmo tempo que servia ao proprietário como reserva de mão de obra e desbravador de fronteiras agrícolas ${ }^{20}$. Num outro tipo de contrato, encontrava-se o foreiro, um arrendatário das terras marginais do engenho, que pagava renda em dinheiro e em trabalho na colheita e no plantio, o conhecido Cambão.

O mais significativo nestas relações contratuais de uso da terra foi o fato de que foram elas as formas possíveis encontradas pela força de trabalho para se arranjar diante da expropriação e dos interesses das classes dominantes, desde os primórdios da colonização brasileira até as décadas de 1950/1960, propostos como periodização deste artigo.

Da leitura e análise das correspondências trocadas entre o Centro Radiofônico de Nazaré da Mata e o conjunto de escolas que compunham este sistema, conseguimos obter informações acerca das relações de trabalho e de produção, assim como das relações de propriedade e uso da terra que envolviam as comunidades rurais e os trabalhadores das escolas de rádio.

Toda a região rural atingida por este sistema ${ }^{21}$ ligava-se, majoritariamente, à produção canavieira, e os alunos do MEB se articulavam à produção de cana e açúcar mediante diferentes relações de trabalho, combinando, por sua vez, diversas possibilidades de uso e posse da terra.

\footnotetext{
${ }^{18}$ MARTINS, J. S. O Poder do Atraso: ensaios de sociologia da história lenta, p. 60-61.

${ }^{19}$ ANDRADE, M. C. Op. cit., p. 97.

${ }^{20}$ FORMAN, S. Op. cit., p. 54.

${ }^{21}$ Procuramos, com as informações retiradas das cartas, recuperar o conjunto de cidades, vilas e pequenas localidades que compunham o sistema de Nazaré da Mata; com tais informações construímos um mapa onde localizamos diversos lugarejos e municípios que compunham o sistema de Nazaré. Este mapa encontra-se à disposição para consulta na íntegra da tese : SOUZA, C. S. "Pelas Ondas do Rádio": Camponeses, Cultura Popular e o MEB. Tese de Doutoramento. FFLCH/USP. São Paulo, 2007.
} 
Na diversidade das relações de trabalho o homem rural continuou categorizando-se como camponês, mesmo diante de uma realidade que, em princípios dos anos 60, demarcava-se pelo claro processo de expropriação, que distanciava, cada vez mais, o camponês da possibilidade de propriedade e/ou posse sobre a terra, aproximando-o, muito mais, de um processo de proletarização e assalariamento.

Na região açucareira da Mata Norte, parte dos trabalhadores da cana residia no engenho ou na usina. Estes a quem chamamos de moradores de condição ou condicioneiros, recebiam casa e o direito de tocarem uma roça, trabalharem e morarem no engenho. A concessão da casa e do roçado era uma estratégia de dominação em que o grande proprietário agregava toda a família do trabalhador às suas terras, garantindo a reprodução da força de trabalho no interior do engenho ou da usina e sua dependência do roçado ou do endividamento no barracão ${ }^{22}$.

O agrupamento destas famílias trabalhadoras formava aquilo que Grabois chamou de um hábitat disperso, um hábitat de casas simples, espalhado por entre os canaviais do engenho, formando comunidades nucleares de trabalhadores residentes. Grabois, que estudou o processo de modernização da Usina Cruangi, próximo ao município de Timbaúba, onde funcionou uma escola do MEB acompanhada por nós entre 1961/1964, descreveu:

(...) a monotonia dos canaviais era quebrada com freqüência por casas ou conjuntos de casas próximas, porém separadas entre si por distâncias consideráveis de cerca de $500 \mathrm{~m}$ ou mais, rodeadas por pequenos roçados e poucas fruteiras $(\ldots)^{23}$.

Segundo este estudo, a morada de condição expressava uma necessidade de solução de problemas ligados à carência de mão de obra, já que nas terras da Mata Norte, o corte da

\footnotetext{
${ }^{22} \mathrm{Na}$ condição de morador de engenho, o trabalhador articula o tempo e o espaço da produção e reprodução em um único locus, o latifúndio. Nesta articulação o proprietário desenvolve formas diversas de apropriação do trabalho e de renda, como, por exemplo, a estratégia do endividamento no barracão. As famílias com dificuldades de locomoção e financeiras desenvolvem a prática das compras no barracão, o que as torna devedoras do proprietário. Estas formas multiplicam as relações de dependência e submissão do trabalho em relação ao capital. A referida prática acompanhou o campo brasileiro desde a utilização da mão de obra estrangeira, no início do século XX na cafeicultura, até os dias atuais, com as práticas já denunciadas de escravidão por dívida em barracão. José de Souza Martins aponta as diversas práticas do barracão em diferentes obras. Ver: MARTINS, José de Souza. Não há Terra para Plantar Neste Verão, 1986 e O Cativeiro da Terra, 1979.

${ }^{23}$ GRABOIS, J. Op. C

it., p. 89.
} 
cana crua, sem a utilização da queimada e com dificuldades topográficas para implantar a mecanização, exigia profundo esforço físico, o que justificava a necessidade da permanência do trabalhador nas usinas e engenhos até momentos muito recentes da história da região ${ }^{24}$.

\section{MUNDO RURAL: TRABALHO E TRABALHADORES}

A morada foi identificada por nós no conjunto de cartas do Centro Radiofônico de Nazaré. Dos municípios de Timbaúba, Nazaré, Aliança, Bom Jardim e Buenos Aires, alunos das escolas rurais de engenhos e usinas da região apontaram o domínio da relação de uso da terra como organizadora de seu cotidiano de condicioneiros. Trabalhavam no domínio do senhor de engenho ou do canavieiro da usina e, por isso, recebiam pagamento; compravam no barracão e nas feiras locais os gêneros necessários para o complemento da subsistência. Moravam no engenho, e, assim, puderam ter roça própria e ainda participar da escola instalada no interior das terras ou nos domínios da usina.

Em suas alusões ao trabalho percebemos o envolvimento total do trabalhador com a cana no período da safra e, consequentemente, um período de entressafra, em que o cultivo de gêneros alimentícios se tornava também de interesse do dono do engenho, a fim de que o trabalhador pudesse garantir a sobrevivência familiar.

Nas cartas, endereçadas dos engenhos e usinas, a figura representativa do aluno que morava e trabalhava na grande propriedade se via dependente do bom relacionamento que conseguisse desenvolver no engenho. Uma trova veiculada entre o material didático do MEB revelava a consciência da dependência e ao mesmo tempo a consciência da exploração desenvolvida pelos moradores:

\footnotetext{
Se o pobre é morador

É obrigado a fazer

Tudo que o patrão exige

E se não obedecer

Ele vem com brevidade

E diz: da propriedade pode desaparecer

O pobre não tem direito

De criar um animal

Ou uma cabra de leite

Porque o patrão feudal
}

\footnotetext{
${ }^{24}$ Idem, p. 86.
} 


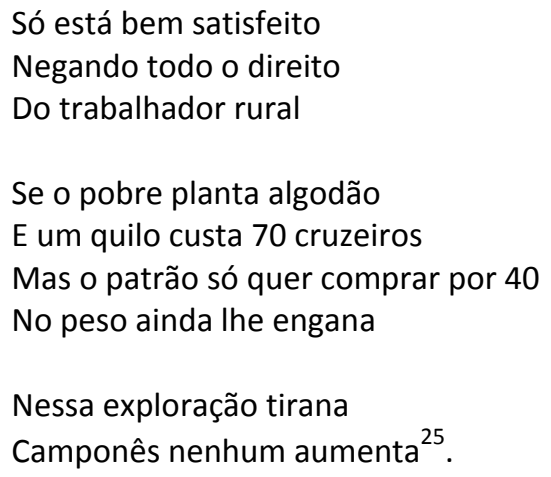

A trova veiculava a consciência da necessidade da obediência como mecanismo mantenedor da relação de dependência entre patrão e trabalhador. No entanto, mesmo sob a consciência da dependência construía-se a crítica à exploração do trabalho. Nas cartas, moradores deixaram registradas duras críticas ao sistema de exploração da situação de morada. Da cidade de Ingá, um aluno que se autointitulou "um morador de engenho" escreveu uma carta às professoras do Centro Radiofônico, discorrendo sobre sua situação:

\author{
Ingá, 11/5/63 \\ Professoras,
}

Eu venho por meio desta fazer-lhe ciente que eu e todos os alunos estamos bem satisfeitos com a escola radiofônica porque é uma facilidade para os pobres poder aprender a ler, mas, a gente não pode ajudar o monitor no que é preciso por pobreza. O nosso estado é miserável aqui nós estamos desgraçados, ganhando duzentos e cinqüenta cruzeiros por dia, sem comida para comprar, tudo, tudo é caro demais... os moradores vivem tudo doente sem dentista e sem médico sofrendo fome é triste a nossa situação. Nós aqui pagamos 12 dias de cambão, além do foro, o cambão é de graça e a seco é assim que os pobres vivem sofrendo no interior. A nossa monitora também sofre as necessidades porque trabalha de noite sem ganhar nada ela está trabalhando de graça. Será que o Estado não pode pagar minhas professoras que são dignas de falar por nós... ${ }^{26}$

Na fala do trabalhador o foro e o cambão foram identificados como sistemas que limitavam os ganhos da mão de obra. O trabalhador interpretava o compromisso com o patrão como impedimento de ampliação de ganhos próprios, ao mesmo tempo que a remuneração paga por seu trabalho não Ihe satisfazia, impondo-lhe a condição de miséria. A crítica ao foro e ao cambão revela, na verdade, a vontade da dedicação exclusiva à lavoura própria, o que não era possível ao morador de condição ou ao foreiro.

\footnotetext{
${ }^{25}$ MEB/PE. A voz do Camponês. S/d. Fundo MEB-CEDIC. Cordel de Autoria de Antonio Teixeira, presidente do Sindicato de Trabalhadores Rurais de Pedro Velho, que compunha os livros de leitura do MEB nos sistemas de Pernambuco e Rio Grande do Norte.

${ }^{26}$ MEB/CEDIC/PUC-SP, Carta.
} 
A situação da prática de lavouras por moradores foi um tema que surgiu nas escolas, por nós percebida através dos conteúdos dos programas de rádio e das cartas. Os programas se dedicaram a responder a uma ampla gama de questionamentos sobre plantios, técnicas de correção do solo, combate de pragas etc. Assim, sabemos que as lavouras persistiram como atividades dos moradores, apartadas da cana, e que interligavam as famílias - pais, mães e filhos - no trabalho agrícola de subsistência.

A prática da lavoura, discutida nos conteúdos das aulas radiofônicas, e a demanda de informações acerca de temas que envolviam o plantio, o controle de lavouras, os melhoramentos agrícolas, entre outros, possibilitaram-nos perceber a existência de um segundo tipo de trabalhadores que frequentaram as escolas do MEB e que se autorreferiam como sitiantes ou pequenos proprietários.

O retalhamento de engenhos nas décadas de 40, 50 e 60 foi uma solução encontrada por grandes proprietários para manter a produção canavieira. Manuel Correia de Andrade afirma que, mesmo diante do processo de concentração fundiária vivido com a instalação das grandes usinas, senhores de engenho, em diversos municípios da Zona da Mata, faziam negócios vendendo pequenas partes de suas propriedades quando as consideravam pouco produtivas ou desvalorizadas, para reaplicar o dinheiro em prol da produção ou em atividades variadas ${ }^{27}$. Mantinha-se uma proximidade do núcleo das grandes propriedades com uma comunidade de pequenos produtores, que, por muitas vezes, a fim de complementar a renda familiar, mesmo proprietários, trabalhavam na coleta da cana no engenho.

Nessas circunstâncias, as escolas rurais instaladas em engenhos e nas usinas reuniram moradores de condição e outros tipos de lavradores, como o pequeno proprietário, que, não dissociado da órbita da grande propriedade, uma vez que residia em território antes pertencente ao grande estabelecimento, adensava a demografia esparsa do hábitat do engenho e/ou usina e frequentava seu espaço regularmente - escola, festas, trabalho.

Nas cartas dos camponeses, a complexidade de relações de trabalho, postas naquele período como sustentadoras das relações de produção da grande lavoura, revelou-se para

\footnotetext{
${ }^{27}$ ANDRADE, M. C. Op. cit., p. 118.
} 
além das circunstâncias da condição, do foro e do predomínio do latifúndio sobre a pequena propriedade. $\mathrm{O}$ assalariamento se fez presente entre parte significativa dos trabalhadores que frequentaram as escolas, surgindo, nos registros do MEB, como uma relação de trabalho de alta variabilidade na grande propriedade canavieira.

$\mathrm{Na}$ documentação encontramos moradores de usinas que frequentaram as escolas e narraram relações de trabalho que os caracterizavam como assalariados residentes na propriedade, sem o direito concedido de lavrar a terra.Em uma condição maior de dependência, recebiam casa para morar dentro da propriedade - a rua da usina - com dedução de aluguel, não tendo direito a terra para cultivo, tornando-se trabalhadores assalariados, dependentes do barracão da usina ou das localidades para a compra de gêneros alimentícios e de primeira necessidade.

Este trabalhador foi chamado de trabalhador alugado, e a menção a este tipo de trabalho foi veiculada intensamente na literatura de cordel que acompanhou a ação didática do MEB e seu projeto de sindicalização ${ }^{28}$. O trabalhador alugado encontrava-se na liminaridade entre o assalariamento e a morada. Ele residia no engenho ou na usina, compactuava das relações de dependência, porém não desfrutava do uso da terra:

Quando trabalha alugado
Isto sim, ninguém nem fala
Nunca chega a juntar
Por sua pequena escala
E é difícil botar
Uma roupinha na mala
Peleja a semana toda
Arranja uma asneirinha
Porém quando chega o sábado
Vai fazer sua feirinha
Pois a mistura que compra
É meio quilo de sardinha (...) ${ }^{29}$.

\footnotetext{
${ }^{28} \mathrm{O}$ MEB desenvolveu seu projeto de cultura popular e alfabetização paralelamente a um projeto específico de sindicalização rural, tema este que mereceu tratamento mais aprofundado na tese da qual este artigo representa apenas parte. $O$ projeto de sindicalização do MEB acompanhou orientações da discussão do Estatuto do Trabalhador em voga no governo Goulart, além de compor a ideologia católica de combate ao projeto sindical do PCB.

${ }^{29}$ MEB/PE. $A$ Vida do Camponês. 1963. FUNDO MEB-CEDIC. O texto do cordel $A$ vida do camponês é de autoria de José Alves da Silva, monitor da escola radiofônica do Sítio Jundiá, da Zona da Mata pernambucana. O folheto foi editado em cordel para circular entre as escolas, tendo pertencido naquele momento à biblioteca circulante do MEB de Pernambuco.
} 
O trabalho alugado foi um tipo de assalariamento característico das usinas de toda a Zona da Mata nordestina, em que o proprietário, mediante desconto em salário, fornecia moradia ao trabalhador e sua família, garantindo a permanência deste nas instalações da usina. Desta forma o dono da terra mantinha o controle da força de trabalho, ao mesmo tempo que garantia que o trabalhador (impedido de lavrar roça) dedicasse todos os dias da semana à produção da cana/açúcar.

$\mathrm{Na}$ condição de alugado o trabalhador ficava à disposição integral do dono do engenho ou da usina. No Engenho Ribeiro Grande, a monitora Emiliana Barata de Morais narrou:

Engenho Ribeiro Grande, 29 de setembro de 1962.

Distintas e boas supervisoras

Ao enviar-Ihes estas linhas é para dar-lhes notícias da escola.

Eu continuo sempre animada e satisfeita. Os alunos estão todos bem interessados e aprendendo, apesar de agora ter começado a safra da cana, e os alunos do sexo masculino, estão perdendo mais aulas, por serem obrigado a encher caminhão de cana à noite, mesmo na hora da aula. São alunos que queriam até sair da escola. Mais eu pedi a eles que não saíssem, comparecessem a noite que pudessem, e assim eles continuam satisfeitos $(\ldots)^{30}$.

O trabalhador alugado era um trabalhador assalariado que não ocupava a posição de um proletário rural, pois havia uma variabilidade do contrato de trabalho que lhe garantia a moradia, o que não impedia a alta exploração do trabalho, ao contrário, era justamente a proximidade física do trabalhador que incentivava o usineiro/dono de engenho a se beneficiar deste tipo de contrato.

A alta variabilidade de contratos revelou também a presença nas usinas e engenhos da figura do trabalhador de fora. Isto significava que este trabalhador morava em vila, localidade ou município próximo ao local de trabalho e se assalariava de forma fixa ou temporária nas propriedades canavieiras.

Devemos ter em conta que nas condições colocadas aos trabalhadores rurais, em princípios de 1960, a proximidade com o engenho ou usina empregadora para facilitar o deslocamento era de fundamental importância na viabilização do trabalho. Tal fato originou

\footnotetext{
${ }^{30}$ Diferentes cartas narram exatamente a mesma situação: as escolas mantendo unicamente a população feminina devido ao fato de os alunos do sexo masculino estarem trabalhando ininterruptamente nos turnos da usina e/ou engenho.
} 
a formação de localidades - pequenas aglomerações muito próximas aos engenhos e usinas - que assumiram a função de comportar a moradia, o comércio e todo um pequeno conjunto de estabelecimentos necessários à sobrevivência básica de famílias assalariadas, como a bodega, a botica, a mercearia, a escola.

No mapeamento da procedência das cartas do MEB, no sistema de Nazaré da Mata, encontramos a menção direta a um amplo conjunto de localidades, marcadas por características rurais e urbanas, assumindo, concomitantemente, a funcionalidade de possibilitar a moradia e a subsistência da mão de obra que já foi expulsa da grande propriedade. Tratava-se de uma população de assalariados, ex-moradores, ex-foreiros, que se aglomerava em bairros periféricos da grande usina, formando as pontas de rua, um hábitat agrupado que circundava a usina com características de um núcleo urbano deficitário. Destas pequenas pontas de rua os monitores escreviam ao MEB comunicando a evasão, mesmo que temporária, de alunos que, na situação de trabalhadores assalariados de fora, deixaram de frequentar as aulas devido à jornada de trabalho nas usinas:

Orobó, 2 de outubro de 1962.

Presadas Supervisoras do Centro Radiofônico

Boa tarde

Neide envio-Ihe esta cartinha dando-Ihe notícias da minha escola. Mandando-lhe dizer que eu estou muito triste porque os meus alunos saíram 6 . Viajaram para trabalhar fora, nas usinas. E eles me disseram que só voltavam lá para novembro. $(\ldots)^{31}$.

A região da Mata combinou o trabalho alugado com o assalariado de fora da usina e/ou engenho, além de conjugar o trabalho assalariado fixo com o temporário. Como trabalhador de fora, a usina também recebia o corumba, um trabalhador assalariado migrante que, residindo no Agreste, Sertão, ou mesmo em determinadas áreas da Mata Norte, se deslocava pelo território oferecendo sua força de trabalho de forma sazonal, no período de colheita da cana ou algodão. De Brejo da Aliança, a monitora Alaíde Serafim explicitou à Neide, professora do Centro Radiofônico de Nazaré, suas preocupações com a diminuição do número de alunos após a safra, quando os corumbas retornaram aos seus locais de origem:

\footnotetext{
${ }^{31}$ Ao menos cinco cartas do sistema de Nazaré narram situação de abandono da escola em decorrência da busca de trabalho temporário.
} 
Brejo de Aliança, 5 de agosto de 1962.

Neide, meu abraço, desejo que esta encontre todas vocês professoras sempre felizes como sempre.

Olhe eu escrevo dando notícias de minha escola estar muito bem, meus alunos muito satisfeitos.

Olhe diminuiu muito os meus alunos depois da chuva porque muitos moram no interior e foram embora, mas o pouco que tem está muito adiantado.(... $)^{32}$.

Os corumbas frequentavam a escola durante sua permanência na Mata Norte e posteriormente se deslocavam para suas regiões de origem. Em outros casos, encontramos trabalhadores sazonais da região de Nazaré que se deslocavam pelo território em busca de trabalho:

Sítio Varjão, 29-9-1962.

Prezadas supervisoras

O objetivo desta cartinha é para dar-Ihes notícias da minha escola. Vários alunos foram as usinas trabalhar porque a situação aqui está ruim por falta de dinheiro, mas eles levaram os livros para estudar lá. Os outros estão bem satisfeito com as aulas de matemática e de linguagem (...)

Eva Maria da Silva ${ }^{33}$.

Nas escolas do MEB estiveram presentes diferentes categorias de assalariados, e as escolas instaladas diretamente nos engenhos e/ou usinas receberam uma diversidade maior de trabalhadores: moradores de condição, sitiantes dos arredores, moradores assalariados, trabalhadores de fora e muitos corumbas.

Em períodos do ano letivo que coincidiam com a safra da cana, pudemos perceber a preocupação dos monitores e professores do rádio com o aluno que necessitava abandonar a escola sem realizar os exames semestrais finais, devido ao deslocamento em busca de trabalho na cana ou em outras lavouras:

Sítio Salobro, 2 de outubro de 1962.

Prezadas supervisoras

Eu ao escrever esta, estou dando minhas notícias de minha escola.

Falando sobre a animação dos alunos a freqüência é boa. Neste mês de outubro não, os alunos trabalham nas usinas para arranjar o pão. (...)

Termino com lembranças a todos.

João Batista Ramos ${ }^{34}$.

\footnotetext{
${ }^{32}$ Fundo MEB/CEDIC/PUC-SP, Carta.

${ }^{33}$ Fundo MEB/CEDIC/PUC-SP, Carta.

${ }^{34}$ Fundo MEB/CEDIC/PUC-SP, Carta.
} 
A sazonalidade do trabalho influenciou diretamente na rotina da escola de rádio. Este aluno que não tinha trabalho fixo provinha algumas vezes de outros territórios - do Agreste - ou do interior, como identificaram seus monitores, o que levava o projeto (elaborado para agir sobre uma comunidade fixa na terra) a redimensionar suas proposições. Estes alunos deixavam de frequentar as aulas, que eram obrigatórias, e solicitavam o retorno em períodos, por exemplo, de avaliação, como o mês de novembro, e/ou vice-versa, deixavam as aulas em maio/junho e não cumpriam as avaliações semestrais.

Cada monitor tentava, à sua maneira, não perder o aluno que por questões de trabalho abandonava a escola. Diversas cartas solicitavam orientações dos centros radiofônicos para que estes alunos não perdessem suas matrículas ou a oportunidade de frequentar a escola. A condição do trabalho sazonal foi reconhecida pelos próprios camponeses como condição adversa. A dura rotina a que eram submetidos os corumbas comoveu moradores e pequenos proprietários. O MEB acabava por ter de driblar as orientações quanto à reprovação por frequência, dentre outras, para poder atuar numa realidade tão desfavorável.

As comunidades rurais do Nordeste brasileiro, em princípios dos anos de 1960, encontravam-se em um momento de ruptura com o passado social formalizado, vivenciando transformações em sua estrutura social interna e movendo-se em direção a um pensamento transformador da sociedade. Naquele momento, a quebra de pactos sociais, como o de uso da terra para plantio de subsistência ligado ao direito de moradia, levou trabalhadores rurais à resistência política organizada, rompendo costumes e transmutando praxes, buscando novas atitudes: sindicato, escola, associação rural, projetos de reforma agrária, retiranças, migrações em busca das possibilidades da reprodução social de seu grupo.

Desta maneira, desencadearam-se processos de mudança na vida social das comunidades rurais, materializados em representações e concretizados em atitudes relacionadas diretamente com a sobrevivência cultural e econômica do grupo.

Nesse sentido, a comunidade rural aderiu ao projeto de ação cultural modernizadora do MEB, na medida em que o contexto histórico apresentava um cenário de disputas pela 
modernização em que cabiam tanto as ações reformadoras do trabalhismo de João Goulart, quanto as ações radicais das Ligas Camponesas.

Participar do MEB, para o camponês analfabeto, significava, antes de tudo, uma mudança de condição, porquanto a escola ofertava possibilidades múltiplas. Naquele contexto a escola assumiu um sentido de transposição da condição de analfabeto, iletrado, para uma condição supostamente melhor, daquele que pode ler, escrever, fazer contas no papel, votar em seus governantes e ampliar suas informações acerca de mecanismos que melhorem sua condição social.

\section{CONSIDERAÇÕES FINAIS}

Ao aceitar participar da escola, homens e mulheres do MEB almejavam alterações em suas vidas: mudar as condições de trabalho, mudar as características do lugar, construir uma vida melhor para os filhos, construir um novo cotidiano, mais livre, iluminado pelos livros, pela habilidade de fazer contas, dentre tantas novas possibilidades. Por meio do MEB, as comunidades procuraram se beneficiar de efeitos da modernização - conquistar escolas, efetivar redes de atendimento e assistência médica, dispor de luz elétrica e saneamento básico, acessar as novas formas de comunicação, como o rádio e o cinema.

As demandas por uma modernização que efetivamente apresentasse os benefícios da técnica e do desenvolvimento científico para as populações excluídas ficaram explícitas no conjunto de reivindicações que as comunidades apresentavam às equipes locais do MEB. Depois de instaladas as escolas, as comunidades ampliavam suas exigências ao dono do engenho, ao prefeito do município, ao usineiro, reivindicando luz elétrica, assistência médica, direito ao lazer, direitos do trabalho.

As cartas dos monitores e alunos do MEB, enviadas às equipes locais, apresentamnos um universo popular que compactua com um projeto de desenvolvimento econômico voltado para a melhoria das condições de vida do povo. O discurso da modernização, introduzido nas comunidades pelos mediadores do MEB, foi aceito, ou mais que isso, foi incorporado, ao ponto de passar a compor a pauta de reivindicações das populações 
camponesas nas exigências de sua inserção social, sob condições mais justas, no mercado de trabalho, na sociedade, na cultura, na política.

Diante dos pressupostos da modernização e de um modelo de desenvolvimento econômico demarcado por um forte papel do Estado e pela predominância do capital sobre o trabalho, a cultura popular não demonstrou aspectos rústicos, primitivos, arraigados ao passado e ao conservadorismo, alheios ou contrários aos propósitos da modernização. Ao contrário, das ligas camponesas, dos sindicatos rurais, das escolas do MEB, surgiram proposições de mudança com perspectivas modernizadoras que contestaram a exclusão social e sua maior aliada no Nordeste: a concentração fundiária.

No momento histórico que baliza este artigo, entre 1961 e 1964, homens e mulheres comuns estiveram submetidos a pressões no sentido de reformar seu universo cultural, sua vida cotidiana, seu pensamento, hábitos e valores sociais. Supunha-se que a alfabetização e uma ação cultural direcionada suplantariam problemas do desenvolvimento e da conscientização das comunidades de trabalhadores rurais, desconsiderando-se assim as possibilidades de contribuição efetiva destes homens e mulheres comuns na transformação social e política do país.

As cartas do Fundo MEB revelaram-nos possibilidades de mergulho no universo dos sujeitos históricos ligados ao MEB - trabalhadores rurais, monitores, professores dos centros radiofônicos, padres, militantes católicos -, aguçando nossas intenções de investigação dos processos que envolveram ações de resistências políticas e culturais cotidianas.

Selecionamos cartas escritas entre 1961 e 196435, sendo o maior número delas a correspondência passiva, ou seja, cartas recebidas pelos centros radiofônicos, havendo, em número pouco significativo, um conjunto de correspondências trocadas entre integrantes das equipes locais com integrantes das equipes nacionais do Movimento.

Neste trabalho procuramos tratar da cultura popular não como um objeto homogêneo composto unicamente de elementos do autoritarismo da sociedade colonial, e, muito menos, cultivamos a posição romântica de uma cultura popular libertária. Nas páginas deste trabalho, privilegiamos o homem comum, seu modo de vida e trabalho, suas

\footnotetext{
${ }^{35}$ Selecionamos o período anterior ao golpe, já que depois de 1964 o MEB sofreu um conjunto de modificações estruturais que merecem estudo aprofundado, abrindo espaço para outro trabalho de pesquisa.
} 
representações sociais e suas práticas políticas nos processos de mudança em curso, buscando entender práticas e representações populares, num contexto em que a modernização conservadora encontrou na cultura resistências à exclusão e à ausência de direitos.

Recebido em 16/12/2009

Aprovado para publicação em 22/02/2010 